\title{
Corrosion of $\mathrm{Fe}-2 \% \mathrm{Mn}-0.5 \% \mathrm{Si}$ Steels at $600-800^{\circ} \mathrm{C}$ in $\mathrm{N}_{2} / \mathrm{H}_{2} \mathrm{O} / \mathrm{H}_{2} \mathrm{~S}$ Atmospheres
}

\author{
Min Jung Kimª, Sang Hwan Park ${ }^{\mathrm{b}}$, Dong Bok Lee \\ ${ }^{a}$ School of Advanced Materials Science and Engineering, Sungkyunkwan University, Suwon 440-746, Korea \\ ${ }^{\mathrm{b}}$ Functional Materials Center, KIST, Seoul 130-650, Korea
}

(Received September 19, 2011; revised October 26, 2011; accepted October 28, 2011)

\begin{abstract}
Fe-2\%Mn- $0.5 \% \mathrm{Si}$ alloys were corroded at 600,700 and $800^{\circ} \mathrm{C}$ for up to $70 \mathrm{~h}$ in 1 atm of $\mathrm{N}_{2}$ gas, or 1 atm of $\mathrm{N}_{2} / \mathrm{H}_{2} \mathrm{O}$-mixed gases, or 1 atm of $\mathrm{N}_{2} / \mathrm{H}_{2} \mathrm{O} / \mathrm{H}_{2} \mathrm{~S}$-mixed gases. Oxidation prevailed in $\mathrm{N}_{2}$ and $\mathrm{N}_{2} / \mathrm{H}_{2} \mathrm{O}$ gases, whereas sulfidation dominated in $\mathrm{N}_{2} / \mathrm{H}_{2} \mathrm{O} / \mathrm{H}_{2} \mathrm{~S}$ gases. The oxidation/sulfidation rates increased in the order of $\mathrm{N}_{2}$ gas, $\mathrm{N}_{2} / \mathrm{H}_{2} \mathrm{O}$ gases, and, much more seriously, $\mathrm{N}_{2} / \mathrm{H}_{2} \mathrm{O} / \mathrm{H}_{2} \mathrm{~S}$ gases. The base element of Fe oxidized to $\mathrm{Fe}_{2} \mathrm{O}_{3}$ and $\mathrm{Fe}_{3} \mathrm{O}_{4}$ in $\mathrm{N}_{2}$ and $\mathrm{N}_{2} / \mathrm{H}_{2} \mathrm{O}$ gases, whereas it sulfidized to $\mathrm{FeS}$ in $\mathrm{N}_{2} / \mathrm{H}_{2} \mathrm{O} / \mathrm{H}_{2} \mathrm{~S}$ gases. The oxides or sulfides of $\mathrm{Mn}$ or $\mathrm{Si}$ were not detected from the XRD analyses, owing to their small amount or dissolution in FeS. Since FeS was present throughout the whole scale, the alloys were nonprotective in $\mathrm{N}_{2} / \mathrm{H}_{2} \mathrm{O} / \mathrm{H}_{2} \mathrm{~S}$ gases.
\end{abstract}

Keywords: Fe-Mn alloys, Corrosion, $\mathrm{H}_{2} \mathrm{~S}$

\section{Introduction}

Korea is currently building a $300 \mathrm{MW}$ integrated gasification combined cycle (IGCC) power plant by 2017. U.S., Japan, Germany, and Netherlands are also building and operating IGCC-based coal-fired power plants. IGCC is a technology that turns coal into synthesis gas (syngas). It is the rapidly emerging, advanced power generation system, which promises low emissions and improved efficiency compared to conventional pulverized coal power plants. However, one of the main problems in IGCC is the corrosion occurring by $\mathrm{H}_{2} \mathrm{~S}$ and $\mathrm{H}_{2} \mathrm{O}$ gases within the syngas, which limits operating temperatures and thus the process efficiency. The $\mathrm{H}_{2} \mathrm{~S}$ gas dissociates into sulfur and hydrogen ions, and reacts with metal according to the reaction; $\mathrm{H}_{2} \mathrm{~S}+\mathrm{M} \mathrm{MS}+\mathrm{H}_{2}^{2,3)}$. Also, water vapor in the syngas reacts with metal to generate hydrogen according to the reaction; $\mathrm{H}_{2} \mathrm{O}+\mathrm{M} \mathrm{MO}+\mathrm{H}_{2}$. This can be absorbed by the metal, and dissolved in metal, accelerating the corrosion rates significantly ${ }^{2-4}$. Generally, the sulfidation rates are 10 100 times faster

${ }^{\circ}$ Corresponding author. E-mail : dlee@skku.ac.kr than the oxidation rates because sulfides have much larger defect concentrations, and have lower melting points than the corresponding oxides ${ }^{5-8)}$. Sulfidation is therefore a quite serious problem ${ }^{9-11)}$.

In this study, the $\mathrm{Fe}-2 \mathrm{Mn}-0.5 \mathrm{Si}$ alloy (in wt.\%) sulfidized between 600 and $800^{\circ} \mathrm{C}$ for up to $70 \mathrm{hr}$ in $\mathrm{N}_{2} / \mathrm{H}_{2} \mathrm{O} / \mathrm{H}_{2} \mathrm{~S}$-mixed gases in order to understand its sulfidation behavior in the simulated IGCC gas atmosphere. $\mathrm{Mn}$ and $\mathrm{Si}$ are added during the steelmaking process mainly to remove oxygen from the melt, and increase strength. $\mathrm{Mn}$ is among the most important alloying element for the design of highstrength steels. However, little is reported about the high-temperature sulfidation behavior of $\mathrm{Fe}-2 \mathrm{Mn}$ $0.5 \mathrm{Si}$ in $\mathrm{H}_{2} \mathrm{O} / \mathrm{H}_{2} \mathrm{~S}$-mixed gases. The purpose of this study is to investigate the sulfidation behavior of Fe$2 \mathrm{Mn}-0.5 \mathrm{Si}$ in $\mathrm{N}_{2} / \mathrm{H}_{2} \mathrm{O} / \mathrm{H}_{2} \mathrm{~S}$-mixed gases for the first time. Furthermore, the obtained results were compared with the oxidation test results of the same alloy in the pure $\mathrm{N}_{2}$ gas, and $\mathrm{N}_{2} / \mathrm{H}_{2} \mathrm{O}$-mixed gases.

\section{Experimental Details}

Steel plates with a composition of Fe-2Mn- $0.5 \mathrm{Si}$ 


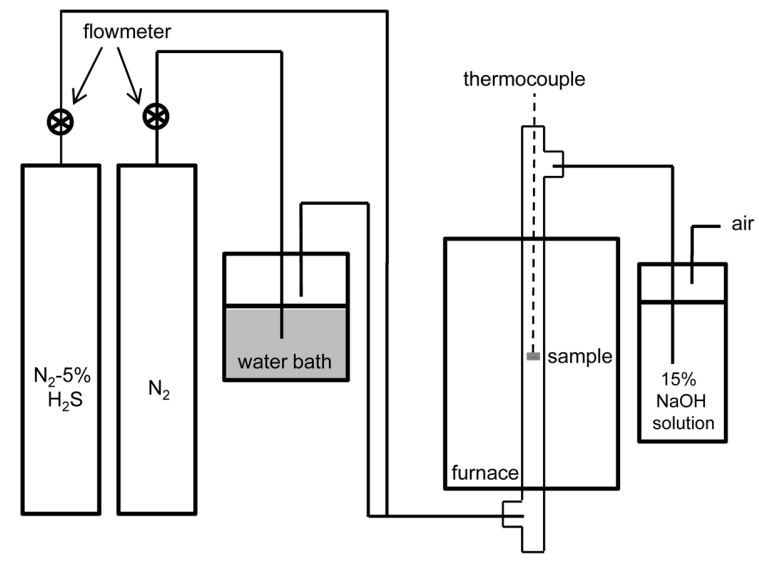

Fig. 1. Corrosion testing apparatus.

were cut into a size of $2 \times 10 \times 15 \mathrm{~mm}^{3}$, ground up to a 1000-grit finish with $\mathrm{SiC}$ paper, ultrasonically cleaned in acetone, and corroded at 600, 700 and $800^{\circ} \mathrm{C}$ for up to $70 \mathrm{~h}$ using an apparatus shown in Fig. 1. Each test coupon was suspended by a Pt wire in a quartz reaction tube within the hot zone of an electrical furnace. Three kinds of atmospheres were employed for corrosion tests. Firstly, $1 \mathrm{~atm}$ of $\mathrm{N}_{2}$ gas. Secondly, a gas mixture of $0.968 \mathrm{~atm}$ of $\mathrm{N}_{2}$ and 0.032 atm of $\mathrm{H}_{2} \mathrm{O}$, which was achieved by bubbling the $\mathrm{N}_{2}$ gas through the water bath kept at $25^{\circ} \mathrm{C}$. Thirdly, a gas mixture of 0.9448 atm of $\mathrm{N}_{2}, 0.031 \mathrm{~atm}$ of $\mathrm{H}_{2} \mathrm{O}$ and $0.0242 \mathrm{~atm}$ of $\mathrm{H}_{2} \mathrm{~S}$, which was achieved by bubbling the $\mathrm{N}_{2}$ gas through the water bath kept at $25^{\circ} \mathrm{C}$, while flowing the $\mathrm{H}_{2} \mathrm{~S}$ gas into the reaction tube. The total pressure of test gases was kept at 1 atm. The employed $\mathrm{N}_{2}$ gas was $99.999 \%$ pure, and $\mathrm{H}_{2} \mathrm{~S}$ gas was $99.5 \%$ pure. The samples were characterized by a scanning electron microscope (SEM), an X-ray diffractometer (XRD) with $\mathrm{Cu}-\mathrm{K}_{\text {á }}$ radiation, and an electron probe microanalyzer (EPMA).

\section{Results and Discussion}

Fig. 2 shows weight gains that were measured using a microbalance without spontaneously spalled scales. An increase in the temperature from 700 to $800^{\circ} \mathrm{C}$ led to the increment of weight gains by $\sim 2$ times in $\mathrm{N}_{2}$, $\mathrm{N}_{2} / \mathrm{H}_{2} \mathrm{O}$, or $\mathrm{N}_{2} / \mathrm{H}_{2} \mathrm{O} / \mathrm{H}_{2} \mathrm{~S}$ gases. Impurities of $3 \mathrm{ppm}$ $\mathrm{H}_{2} \mathrm{O}$ and 2 ppm $\mathrm{O}_{2}$ in the employed $\mathrm{N}_{2}$ gas oxidized the samples. At 700 and $800^{\circ} \mathrm{C}$, the change of gases from $\mathrm{N}_{2}$ to $\mathrm{N}_{2} / \mathrm{H}_{2} \mathrm{O}$ increased the weight gains by 1.1 times, and that from $\mathrm{N}_{2} / \mathrm{H}_{2} \mathrm{O}$ to $\mathrm{N}_{2} / \mathrm{H}_{2} \mathrm{O} / \mathrm{H}_{2} \mathrm{~S}$ increased the weight gains by 6 times. However, it is noted that there was uncertainty in weight gains measured in $\mathrm{N}_{2} /$

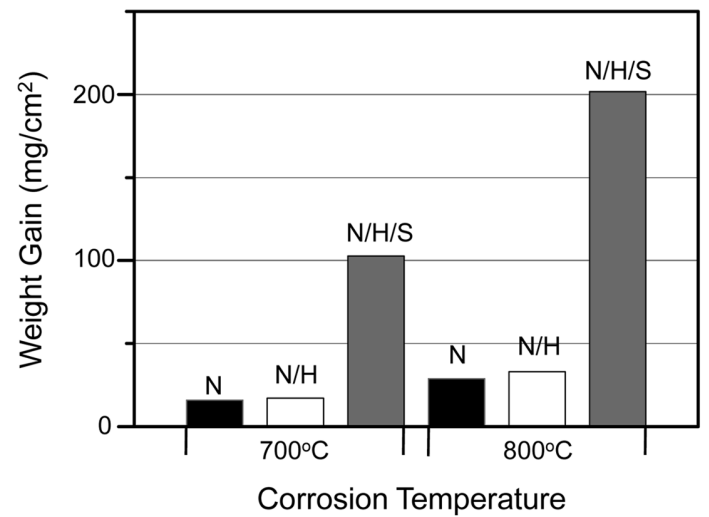

Fig. 2. Weight gains of Fe-2Mn-0.5Si, which were measured after oxidation/sulfidation at 700 and $800^{\circ} \mathrm{C}$ for $70 \mathrm{~h}$. $\mathrm{N}$ means $\mathrm{N}_{2}, \mathrm{~N} / \mathrm{H}$ means $\mathrm{N}_{2} /$ $\mathrm{H}_{2} \mathrm{O}$, and $\mathrm{N} / \mathrm{H} / \mathrm{S}$ means $\mathrm{N}_{2} / \mathrm{H}_{2} \mathrm{O} / \mathrm{H}_{2} \mathrm{~S}$ gases used as oxidation/sulfidation media.

$\mathrm{H}_{2} \mathrm{O} / \mathrm{H}_{2} \mathrm{~S}$-mixed gases, because scales formed in $\mathrm{H}_{2} \mathrm{~S}$ containing atmosphere were usually thick, and highly susceptible to spallation during corrosion and subsequent cooling stage $\mathrm{e}^{1-3)}$. Nevertheless, it was evident that $\mathrm{H}_{2} \mathrm{O}$ and, much more seriously, $\mathrm{H}_{2} \mathrm{~S}$ gas increased the corrosion rates. Water vapor transports in the scale as $\mathrm{H}_{2}(\mathrm{~g})$ and $\mathrm{H}_{2} \mathrm{O}(\mathrm{g})$ within voids, cavities, and cracks, and as $\mathrm{H}$ atom by dissolving in the lattice and thereby affecting point defect concentration ${ }^{2,3)}$.

Fig. 3 shows the XRD patterns of the corroded samples. The scales that formed in $\mathrm{N}_{2}$ and $\mathrm{N}_{2} / \mathrm{H}_{2} \mathrm{O}$ atmospheres consisted primarily of $\mathrm{Fe}_{3} \mathrm{O}_{4}$ as the major phase and $\mathrm{Fe}_{2} \mathrm{O}_{3}$ as the minor one, as typically shown in Figs. 3(a) and (b). Here, the $\mathrm{Fe}_{2} \mathrm{O}_{3}$ layer exists on the $\mathrm{Fe}_{3} \mathrm{O}_{4}$ layer ${ }^{1,2)}$. The scales that formed in $\mathrm{N}_{2} / \mathrm{H}_{2} \mathrm{O}$ / $\mathrm{H}_{2} \mathrm{~S}$ atmosphere consisted primarily of $\mathrm{FeS}$, indicating the sulfidizing tendency was stronger than the oxidizing tendency because of $\mathrm{H}_{2} \mathrm{~S}$ (Figs. 3(c) (f)). $\mathrm{H}_{2} \mathrm{~S}$ reacts with $\mathrm{Fe}$ according to the following reactions.

$$
\begin{aligned}
& \mathrm{Fe} \rightarrow \mathrm{Fe}^{2+}+2 \mathrm{e}^{-} \\
& \mathrm{H}_{2} \mathrm{~S} \rightarrow 2 \mathrm{H}^{+}+\mathrm{S}^{2-} \\
& 2 \mathrm{H}^{+}+2 \mathrm{e}^{-} \rightarrow \mathrm{H}_{2}
\end{aligned}
$$

The net reaction is $\mathrm{Fe}+\mathrm{H}_{2} \mathrm{~S} \rightarrow \mathrm{FeS}+\mathrm{H}_{2}$. FeS has a very high concentration of cation vacancies so that it grows rapidly by the outward diffusion of $\mathrm{Fe}^{++}$ions ${ }^{7)}$. A weak $\alpha$-Fe matrix peak was detected in Fig. 3(c), because the partial spallation of $\mathrm{FeS}$ exposed the underlying matrix. In Fig. 3(d), only FeS was detected, because the X-ray beam could not penetrate the partially spalled FeS scale. In order to examine the inner scale, the outer scale was abraded off, and the inner scale was X-rayed, as shown in Fig. 3(e). Here, 


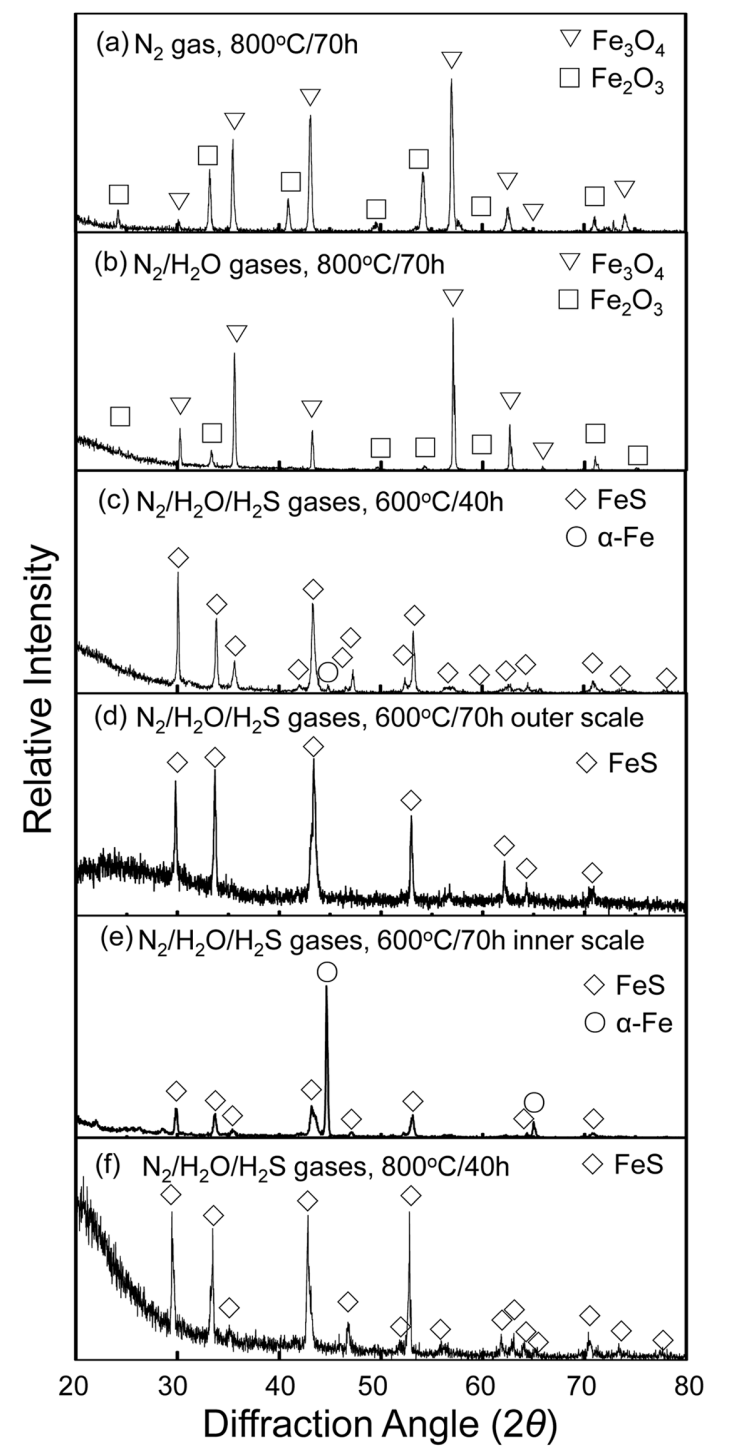

Fig. 3. XRD patterns of scales formed on Fe-2Mn-0.5Si after oxidation/sulfidation. (a) $\mathrm{N}_{2} / 800^{\circ} \mathrm{C} / 70 \mathrm{~h}$, (b) $\left(\mathrm{N}_{2} / \mathrm{H}_{2} \mathrm{O}\right) / 800^{\circ} \mathrm{C} / 70 \mathrm{~h}$, (c) $\left(\mathrm{N}_{2} / \mathrm{H}_{2} \mathrm{O} / \mathrm{H}_{2} \mathrm{~S}\right) / 600^{\circ} \mathrm{C} / 40 \mathrm{~h}$, (d) $\left(\mathrm{N}_{2} / \mathrm{H}_{2} \mathrm{O} / \mathrm{H}_{2} \mathrm{~S}\right) / 600^{\circ} \mathrm{C} / 70 \mathrm{~h}$-outer scale, (e) $\left(\mathrm{N}_{2} / \mathrm{H}_{2} \mathrm{O} / \mathrm{H}_{2} \mathrm{~S}\right) / 600^{\circ} \mathrm{C} / 70 \mathrm{~h}$-inner scale, (f) $\left(\mathrm{N}_{2} /\right.$ $\left.\mathrm{H}_{2} \mathrm{O} / \mathrm{H}_{2} \mathrm{~S}\right) / 800^{\circ} \mathrm{C} / 40 \mathrm{~h}$.

FeS was found together with the $\alpha-\mathrm{Fe}$ matrix. Also in Fig. 3(f), only FeS was detected. Hence, it is seen that $\mathrm{H}_{2} \mathrm{~S}$ always forms FeS. When the samples corroded in $\mathrm{N}_{2}, \mathrm{~N}_{2} / \mathrm{H}_{2} \mathrm{O}$, and $\mathrm{N}_{2} / \mathrm{H}_{2} \mathrm{O} / \mathrm{H}_{2} \mathrm{~S}$ gases, no oxides or sulfides of $\mathrm{Mn}$ or $\mathrm{Si}$ were detected from the XRD analyses, due to their small amount or dissolution in FeS.

The sample whose XRD pattern is shown in Fig. 3(a) was examined using SEM, as shown in Fig. 4. Fine $\mathrm{Fe}_{2} \mathrm{O}_{3}$ grains had a slightly rugged surface (Fig. 4(a)). The scale was $\sim 150 \mu \mathrm{m}$ thick, and broken into two parts (Fig. 4(b)). In the scale that consisted primarily of $\mathrm{Fe}_{3} \mathrm{O}_{4}$ and $\mathrm{Fe}_{2} \mathrm{O}_{3}, \mathrm{Mn}$ was rather
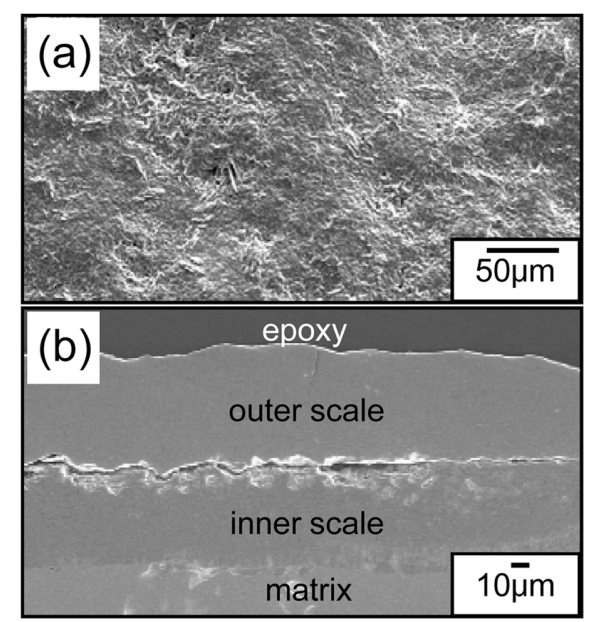

(c)

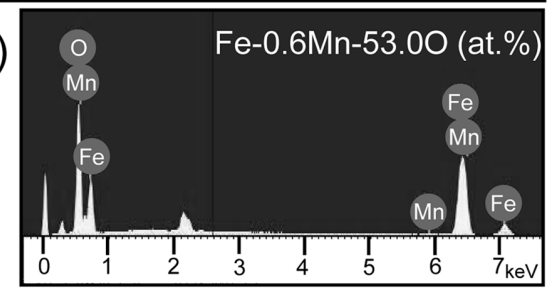

(d)

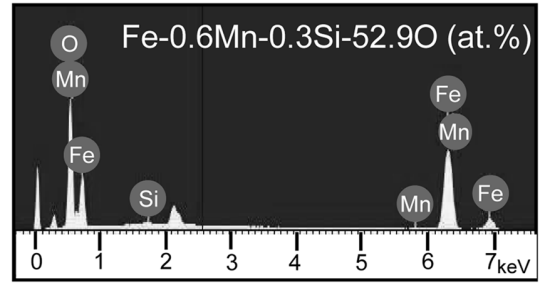

Fig. 4. Fe-2Mn-0.5Si after oxidation at $800^{\circ} \mathrm{C}$ for $70 \mathrm{~h}$ in $\mathrm{N}_{2}$ atmosphere. (a) SEM top view, (b) crosssectional image, (c) EDS spectrum of the outer scale, (d) EDS spectrum of the inner scale.

uniformly distributed (Figs. 4(c) and (d)). However, $\mathrm{Si}$ was segregated in the inner scale, because $\mathrm{Si}$ ions were relatively immobile owing to the high bonding energy of $\mathrm{Si}^{4+}-\mathrm{O}^{2-}\left(465 \mathrm{kJmol}^{-1}\right)^{12)}$.

The sample whose XRD pattern is shown in Fig. 3(b) was examined using SEM, as shown in Fig. 5. The $\mathrm{Fe}_{2} \mathrm{O}_{3}$ scale had a rather flat surface (Fig. 5(a)). Its thickness increased to $\sim 240 \mu \mathrm{m}$ (Fig. 5(b)). Cracks developed at the surface and middle of the scale, the main cause of which was attributed to stresses developed in the thick oxide scale. Again, $\mathrm{Si}$ was segregated in the inner scale, although $\mathrm{Mn}$ was distributed rather uniformly throughout the whole oxide scale (Figs. 5(c), (d)). The scale morphology and elemental distribution of Fig. 5 were similar with those of Fig. 4, because the principal oxidation mode was the same in $\mathrm{N}_{2}$ and $\mathrm{N}_{2} / \mathrm{H}_{2} \mathrm{O}$ atmospheres. The main difference was the acceleration of corrosion rates by $\mathrm{H}_{2} \mathrm{O}$. The compositional difference between the outer and inner oxide layers seemed to aggravate 

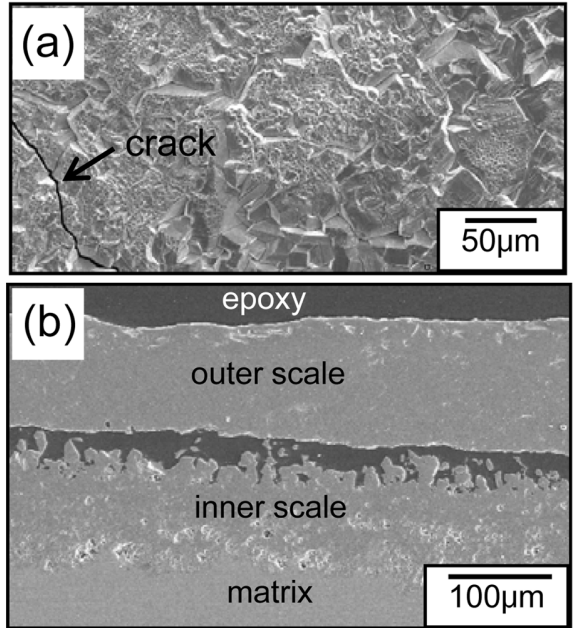

(c)

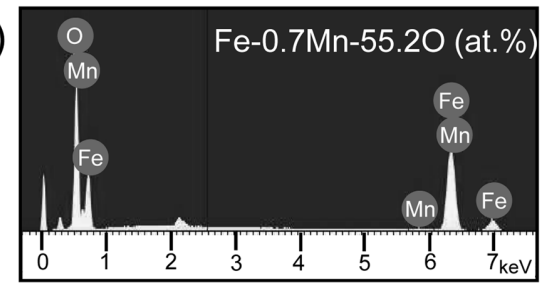

(d)

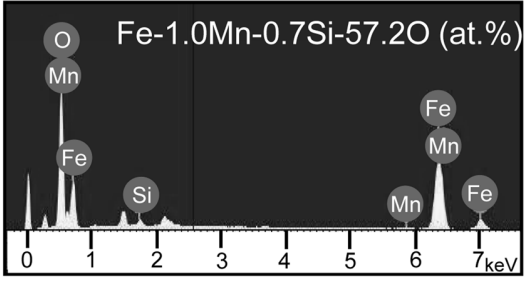

Fig. 5. Fe-2Mn-0.5Si after oxidation at $800^{\circ} \mathrm{C}$ for $70 \mathrm{~h}$ in $\mathrm{N}_{2} / \mathrm{H}_{2} \mathrm{O}$ atmosphere. (a) SEM top view, (b) cross-sectional image, (c) EDS spectrum of the outer scale, (d) EDS spectrum of the inner scale.

stresses in the scale, facilitating the crack propagation in Figs. 4 and 5.

The sulfidation behavior of the samples in $\mathrm{N}_{2} / \mathrm{H}_{2} \mathrm{O} /$ $\mathrm{H}_{2} \mathrm{~S}$ atmosphere was examined in detail, as shown in Figs. 6 9. Weight gains measured after sulfidation at 600,700 and $800^{\circ} \mathrm{C}$ for up to $70 \mathrm{~h}$ are displayed in Fig. 6 . They are the sum of weight gain due to scaling and weight loss due to scale spallation. Large weight gains were recorded in Fig. 6, indicating vastly fast sulfidation kinetics. The scale failure became more serious as sulfidation progressed. Local cracking, partial spallation and void formation in the formed sulfide scales were unavoidable, the extent of which varied for each test run. Hence, weight gains depicted in Fig. 6 should be regarded as approximate values. However, the major trends can be observed in Fig. 6 as follows. The sulfidation appeared to follow the linear rate law, implying negligible protection owing to the formation of FeS. Mn and Si could not protect the alloy from the serious sulfidation, due to their small

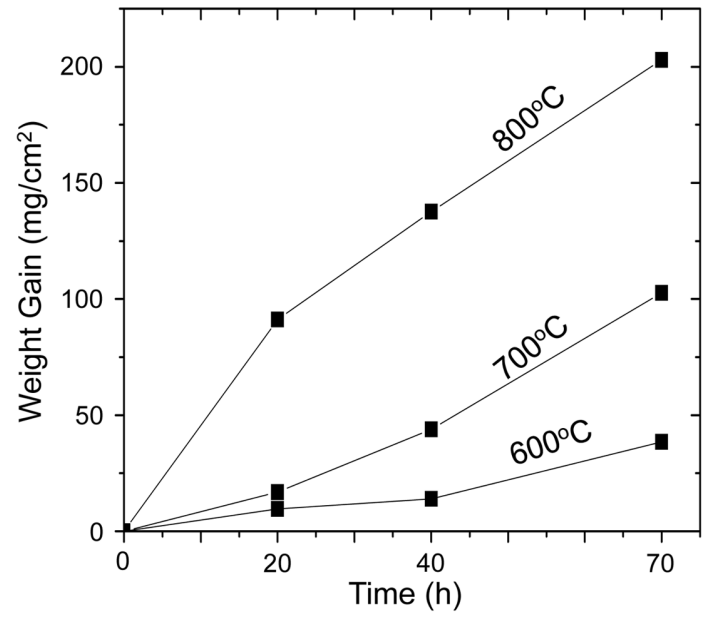

Fig. 6. Weight gain versus sulfidation time curves of Fe-2Mn-0.5Si at 600,700 and $800^{\circ} \mathrm{C}$ for $70 \mathrm{~h}$ in $\mathrm{N}_{2} / \mathrm{H}_{2} \mathrm{O} / \mathrm{H}_{2} \mathrm{~S}$ atmosphere.
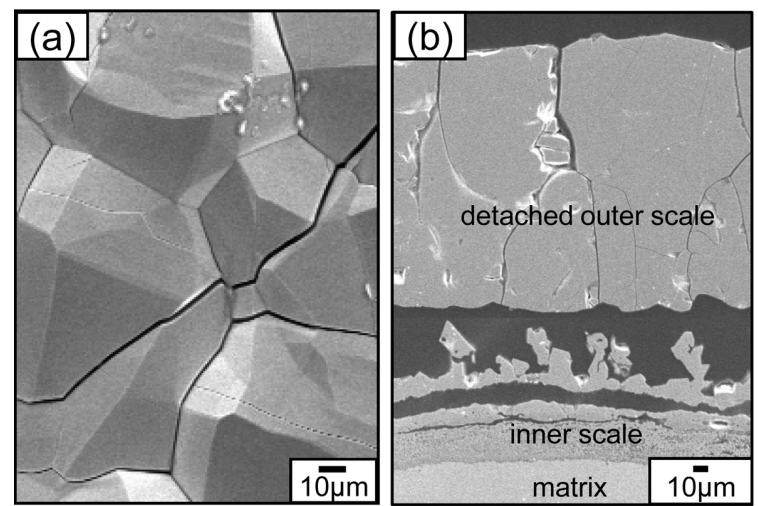

Fig. 7. Fe-2Mn-0.5Si after sulfidation at $700^{\circ} \mathrm{C}$ for $20 \mathrm{~h}$ in $\mathrm{N}_{2} / \mathrm{H}_{2} \mathrm{O} / \mathrm{H}_{2} \mathrm{~S}$ atmosphere. (a) SEM top view, (b) cross-sectional image.

amount or dissolution in FeS.

The scale that formed after sulfidation at $700^{\circ} \mathrm{C}$ for $20 \mathrm{~h}$ in $\mathrm{N}_{2} / \mathrm{H}_{2} \mathrm{O} / \mathrm{H}_{2} \mathrm{~S}$ atmosphere were analyzed, as shown in Fig. 7. Fig. 7(a) shows outer, coarse, faceted $\mathrm{FeS}$ grains. Cracks propagated inter- and trans-granularly, because the formation of $\mathrm{FeS}$ from $\mathrm{Fe}$ resulted in $261 \%$ volume expansion. $\mathrm{FeS}$ was fragile, and nonadherent because it grew fast and formed voids at the scale-matrix interface ${ }^{13)}$. In Fig. 7(b), the outer thick FeS scale detached off, and the inner fragile FeS scale split into a few layers. The total thickness of the scale was $\sim 270 \mu \mathrm{m}$, implying poor sulfidation resistance. The outer FeS layer had either an equiaxed or a columnar structure, and the inner layer consisted of fine grains. The inner $\mathrm{FeS}$ dissociates according to the reaction; $\mathrm{FeS}=\mathrm{Fe}^{2+}+1 /$ $2 \mathrm{~S}_{2}+2 \mathrm{e}^{14)}$. This delivers $\mathrm{S}$ gas for the inward growth of the innermost layer, and the released iron ions and electrons diffuse to the outer surface to form FeS. 

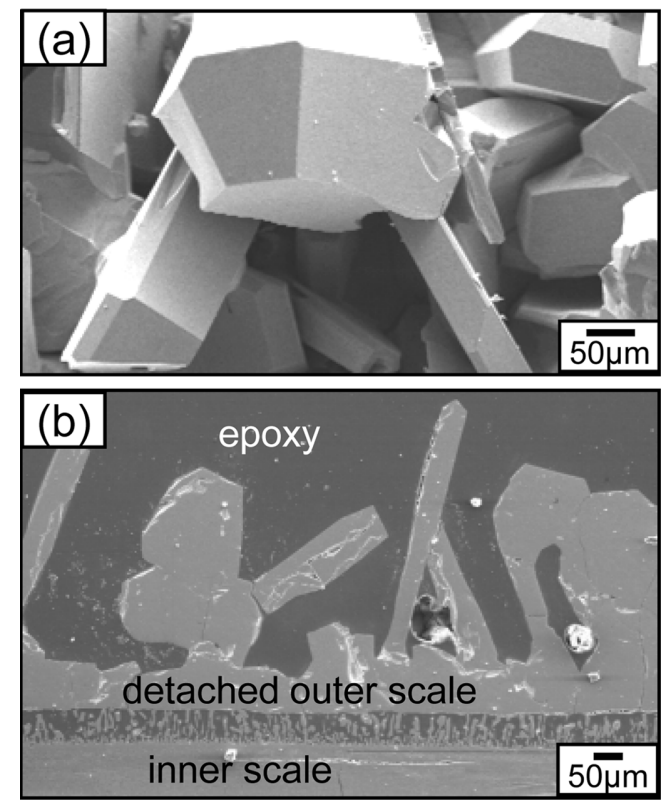

Fig. 8. Fe-2Mn-0.5Si after sulfidation at $700^{\circ} \mathrm{C}$ for $70 \mathrm{~h}$ in $\mathrm{N}_{2} / \mathrm{H}_{2} \mathrm{O} / \mathrm{H}_{2} \mathrm{~S}$ atmosphere. (a) SEM top view, (b) cross-sectional image.
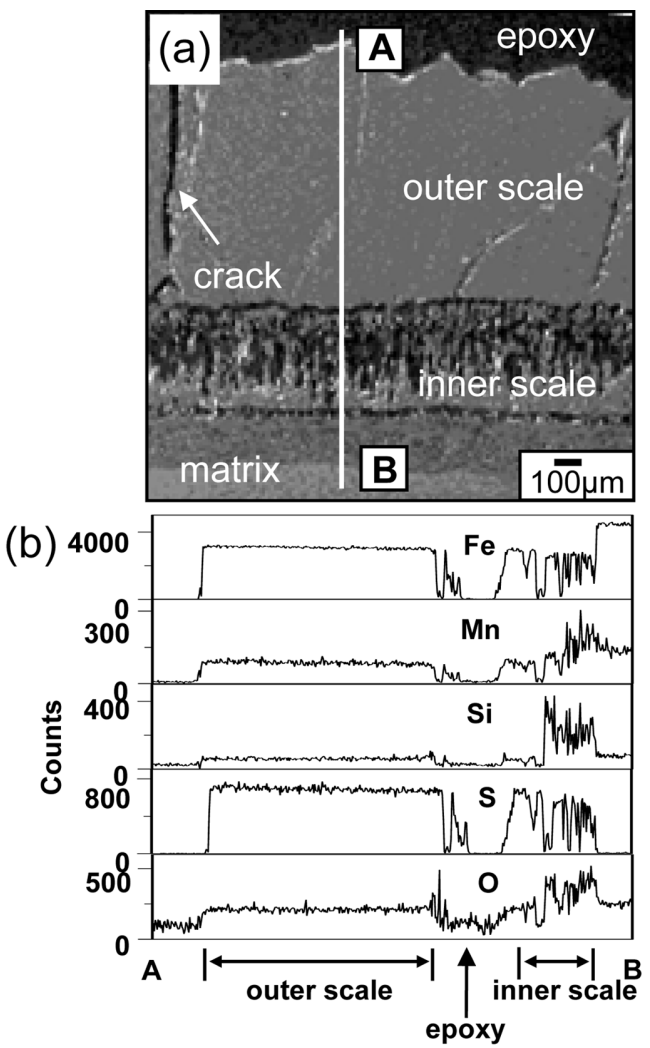

Fig. 9. Fe-2Mn-0.5Si after sulfidation at $800^{\circ} \mathrm{C}$ for $70 \mathrm{~h}$ in $\mathrm{N}_{2} / \mathrm{H}_{2} \mathrm{O} / \mathrm{H}_{2} \mathrm{~S}$ atmosphere. (a) EPMA crosssectional image, (b) line profiles.

The sample was sulfidized further for $70 \mathrm{~h}$ at $700^{\circ} \mathrm{C}$, as shown in Fig. 8. The outer FeS grains kept growing into the air, as $\mathrm{Fe}$ continuously diffused out from the matrix via the pre-formed $\mathrm{FeS}$ grains to the outermost surface (Fig. 8(a)). Here, excessively coarse $\mathrm{FeS}$ grains were protruded into the air. The outer scale was thicker than the inner scale (Fig. 8(b)). The outer, fast-growing $\mathrm{FeS}$ grains were susceptible to cracking and detached off from the inner mixed scale, owing to the serious, compressive stress developed. Cracking and spallation of scales facilitated the ingress of corrosive gases, making the sample sulfidize almost linearly, as shown in Fig. 6.

The scale formed after sulfidation at $800^{\circ} \mathrm{C}$ for $70 \mathrm{~h}$ was analyzed using EPMA, as shown in Fig. 9. It was quite thick, brittle, cracked and detached easily (Fig. 9(a)). In Fig. 9(b), Mn, Si, and oxygen were incorporated in the FeS scale. The outer scale formed by the outward transport of predominantly $\mathrm{Fe}$ and a small amount of $\mathrm{Mn}$ and $\mathrm{Si}$, whereas the inner scale formed by the inward diffusion of predominantly sulfur and a small amount of oxygen along cracks, and interconnected pores that developed particularly around the interface of the outer and inner scale.

\section{Conclusions}

The Fe-2Mn- $0.5 \mathrm{Si}$ alloys were oxidized or sulfidized at 600,700 and $800^{\circ} \mathrm{C}$ for up to $70 \mathrm{~h}$ in $\mathrm{N}_{2}$, or $\mathrm{N}_{2} / \mathrm{H}_{2} \mathrm{O}$, or $\mathrm{N}_{2} / \mathrm{H}_{2} \mathrm{O} / \mathrm{H}_{2} \mathrm{~S}$ gases under total pressure of $1 \mathrm{~atm}$. In $\mathrm{N}_{2}$ or $\mathrm{N}_{2} / \mathrm{H}_{2} \mathrm{O}$ gases, $\mathrm{Fe}_{2} \mathrm{O}_{3}$ and $\mathrm{Fe}_{3} \mathrm{O}_{4}$ formed. $\mathrm{H}_{2} \mathrm{O}$ stimulated the oxidation rates by 1.1 times, and $\mathrm{H}_{2} \mathrm{~S}$ further accelerated the corrosion rates by 6 times. In $\mathrm{N}_{2} / \mathrm{H}_{2} \mathrm{O} / \mathrm{H}_{2} \mathrm{~S}$ gases, sulfidation occurred almost linearly. The outer scale consisted primarily of $\mathrm{FeS}$ that formed by the outward diffusion of iron. The inner scale formed by the inward diffusion of predominantly sulfur and a small amount of oxygen. The outer scale was coarse, the inner scale was fine, and the whole sulfide scale was nonadherent, and susceptible to cracking.

\section{Acknowledgments}

This work was supported by New \& Renewable Energy R\&D program (2009T00100316) under the Ministry of Knowledge Economy, Republic of Korea.

\section{References}

1. N. Birks, G. H. Meier, Introduction to High Temperature Oxidation of Metals, Cambridge University Press, UK, 2 (2006) 183. 
2. D. J. Young, High Temperature Oxidation and Corrosion of Metals, (2008) 455.

3. J. Shen, L. Zhou, T. Li, Oxid. Met., 48 (1997) 347.

4. F. Lang, Z. Yu, S. Gedevanishvili, Intermetallics, 12 (2004) 469.

5. R. E. Lobning, H. J. Grabke, Corros. Sci., 30 (1990) 1045.

6. J. C. Dobson, F. R. McLarnon, E. J. Cairns, Corros. Sci., 28 (1988) 953.

7. S. Mrowec, K. Przybylski, Oxid. Met., 23 (1985) 107.

8. S. Mrowec, T. Walec, T. Werber, Oxid. Met., 1
(1969) 93.

9. S. Mrowec, M. Wedrychowska, Oxid. Met., 13 (1979) 481

10. M. Danielewski, S. Mrowec, A. Stolosa, Oxid. Met., 17 (1982) 77.

11. R. John, Shreir's Corrosion, Elsevier, UK 1 (2010) 240.

12. P. Kofstad, Oxid. Met., 44 (1995) 3.

13. S. Mrowec, Oxid. Met., 1 (1995) 177.

14. M. Schulte, A. Rahmel, M. Schutze, Oxid. Met., 49 (1998) 33. 